( ) Journal of Open Innovation: Technology, Market, and Complexity a SpringerOpen Journal

\title{
RESEARCH
}

Open Access

\section{Historical review on the patterns of open innovation at the national level: the case of the roman period}

\author{
Jeong-hwan Jeon ${ }^{1}$, Sung-kyu Kim ${ }^{1}$ and Jin-hwan Koh ${ }^{2 *}$
}

\author{
* Correspondence: jikoh@gnu.ac.kr \\ ${ }^{2}$ Department of Electronics \\ Engineering/ERI, Gyeongsang \\ National University, \\ Gyeongsangnam-do, Korea \\ Full list of author information is \\ available at the end of the article
}

\begin{abstract}
As a result of the open innovation dissemination, the necessity of open innovation is being magnified in the theory of national innovation system. Nevertheless, research on the relationship between the open innovation and national innovation system is insufficient so far. Therefore, this research aims to analyze the open innovation cases of Roman era with the framework of national innovation system. We discovered and analyzed the case of Roman era such as Acquisition, In-sourcing, Collaboration, User innovation and Spin-off among the several type of open innovation. We expect that this research can help the establishment of future national innovation policy.
\end{abstract}

Keywords: Open innovation, National innovation system, Roman era

\section{Background}

The concept of open innovation has been recently hailed to be a new R\&D strategy following the diversification of consumer demands and corporate competition, and the need for responsive and continuous innovation that they require (Chesbrough; 2003). The recognition of open innovation has been expanding widely among corporations (Schiele; 2010), and there has been a continuous demand to realize the concept in a national level (Vanhaverbeke and Cloodt, 2006; West et al. 2006). For a nation to realize such innovation, it is forced to rely on external resources (human, technology, capital, etc.). However, a national innovation system (NIS), which actively creates and disseminates knowledge, can overcome its initial lack of resources, manpower, and knowledge and pursue its forerunners by the virtue of rapid and effective acquisition of technology (Freeman, 1987; OECD; 1992). Consequently, Chesbrough (2003) has presented a model of the relationship between the NIS of the United States and open innovation as well as analyzed that the changes in the NIS of the United States has catalyzed the emergence of open innovation. Several advanced nations, including the OECD member states, have focused on the strategy of open innovation to strengthen and improve the capacity for science and technological innovation on national level. In addition, they have been carrying out relevant activities accordingly (Jang and Lee; 2009).

However, the literature on the relationship between NIS and open innovation remains limited (Wang et al. 2012; De Jong et al. 2010). The majority of the studies on 
the literature regarding the NIS has focused only on the structure, function, effect, and types of such system (Lundvall, 1992; Lee, 2009). Likewise, the majority of the studies regarding open innovation has focused solely on presenting case studies centered around corporations (Chesbrough, 2003; Gassmann and Reepmeyer, 2005), the relationship and the effect between innovation and R\&D collaboration (Amara and Landry 2005; Kline, 2003; Lichtenthaler, 2008), as well as the results and the effects of R\&D with regards to the types of partners in collaboration (Eom and Lee, 2010; Belderbos et al. 2004).

Thus, this study shall present a historical case study analysis of the application of open innovation in NIS and derive points of reference to the examples of open innovation being applied in the context of the NIS. This study has selected the Roman period as the subject. The Roman period refers to the ancient civilization that had started from a small village in the middle of the Italian Peninsula, eventually growing into a gigantic empire spanning the entire Mediterranean Sea. This study shall look at the examples of open innovation during the building of such a great empire and present its analysis based on the NIS.

This study consists of the following parts. Chapter 2 shall look at the concepts of NIS and open innovation as well as the historical significance of the Roman period. Chapter 3 will present the individual case studies. Chapter 4 will present the conclusion of the study and the recommendations for future researches.

\section{Previous literature}

NIS

The NIS theory is developed from the historical experience that the technological innovation of a nation is dependent not only on the scientific and technological capability of a nation but also its socio-economic conditions. The theory was conceived from the analysis on why the Japanese economy during the 1980s showed greater growth compared to United States and Europe (Lee et al., 2007). The definitions given to the NIS include "the network between public and private organizations that conduct technological development and interactions to acquire, improve, and disseminate new technology (Freeman, 1987)," "all parts of economic system and institutional organizations, which affect exploration, inquiry, and learning (Lundvall, 1992)," as well as "national systems that determine the speed and direction of technological acquisition, their incentive system, and competitiveness (Patel and Pavitt, 1994)." Across all definitions, however, the NIS adopts a systemic approach to overcome the limitations posed by a linear approach to technological innovation process (Seo, 1998). Such a systemic approach upholds that the overall success of an economy is not dependent on how specific official institutions (corporations, research institutions, universities, etc.) perform, but rather, it is dependent on how they interact as constituents of an overarching system that creates and uses knowledge and how they interact to social institutions such as values, norms, and laws (OECD, 1997). OECD (1999) has mentioned that the NIS is composed of corporate networks, research institutions, support institutions, and scientific systems that are centered around corporatedriven reforms, and it is dependent on their interactions. Specifically, the OECD 
mentioned the need for an organizing entity that establishes technological and innovation policies, conducts $R \& D$, provides financial support to $R \& D$, and fosters human resource development, technological dissemination, and entrepreneurship (OECD, 1999). The NIS is made up of three major elements, including technological innovation process, closed system elements, and open system elements (Lee, 1996). By subdividing them, important elements, such as innovative agents (made up of groups such as corporations, universities, research institutions, policymakers, and individuals), their networks (such as interactions in market and nonmarket context) (Koo et al. 2012), and dynamic interactions (Lim, 2003, 2006; Lee et al. 2012) shall be included. Thus, the NIS is a collection of entities that produce, disseminate, and adopt new technological knowledge, and the activeness of the collaboration and dissemination made through the interactions of the constituents in the system can be counted as a sign of an outstanding NIS (Moon, 2006; Hong, 2007). By doing such, the NIS carries out functions, including creating knowledge, setting directions for future inquiries, providing resources, deriving externalities, and promoting the formation of markets (Johnson and Jacobsson 2003). To better understand the interactions among the elements, an NIS model and its infrastructure must be presupposed (Lee and Song, 1998). Lee and Song (1998) has proposed a model of the infrastructure, which is subdivided into five areas, including technological innovation system in the private sector, government policy, international economy and technological environment, domestic economy and institution, as well as domestic science-technology infrastructure. In the technological innovation system of the private sector, entities such as corporate users, corporate producers, material and component corporations, corporate competitors, and final consumers are considered as the source of technological innovation and an affecting element. The types of government policy include technological demand policy, supply policy, dissemination policy, and $R \& D$ investment policy, while government $R \& D$ investment and policies serve to support or promote technological innovations (Hong and Lim, 1999). The elements in international economics and technological environment include the demands and the needs of the clients and buyers in the overseas export area, as well as the characteristics and learning patterns of the local businessmen's foreign investment activities. The elements relevant to the domestic economy and institutional context include social awareness on the technological innovations of financial support norms, which is the degree of conservativeness based on the reaction to technological innovations in finance institutions, while the elements in the domestic science and technological infrastructure include information dissemination, linkage, and support organizations (Lee and Song, 1998; Hong and Lim, 1999).

Figure 1 presents a summary of the structure and the constituents of the NIS. The constituents of the NIS, the institutional context, the domestic economy and policy environment, as well as the international economy and technological environment (Lee and Song, 1998; Hong and Lim, 1999; Song, 2009) form the environmental and technological context, which serves as a framework for technological innovations. Also, the internal circle is made up of science and technological system (Lee and Song, 1998; Hong and Lim, 1999; OECD, 1999), the agents of innovation (Lim 2006; Koo et al. 2012), and their interactions (Lee, 1996; Hong and Lim 1999; Lim, 2003, 2006; Koo et al. 2012), 


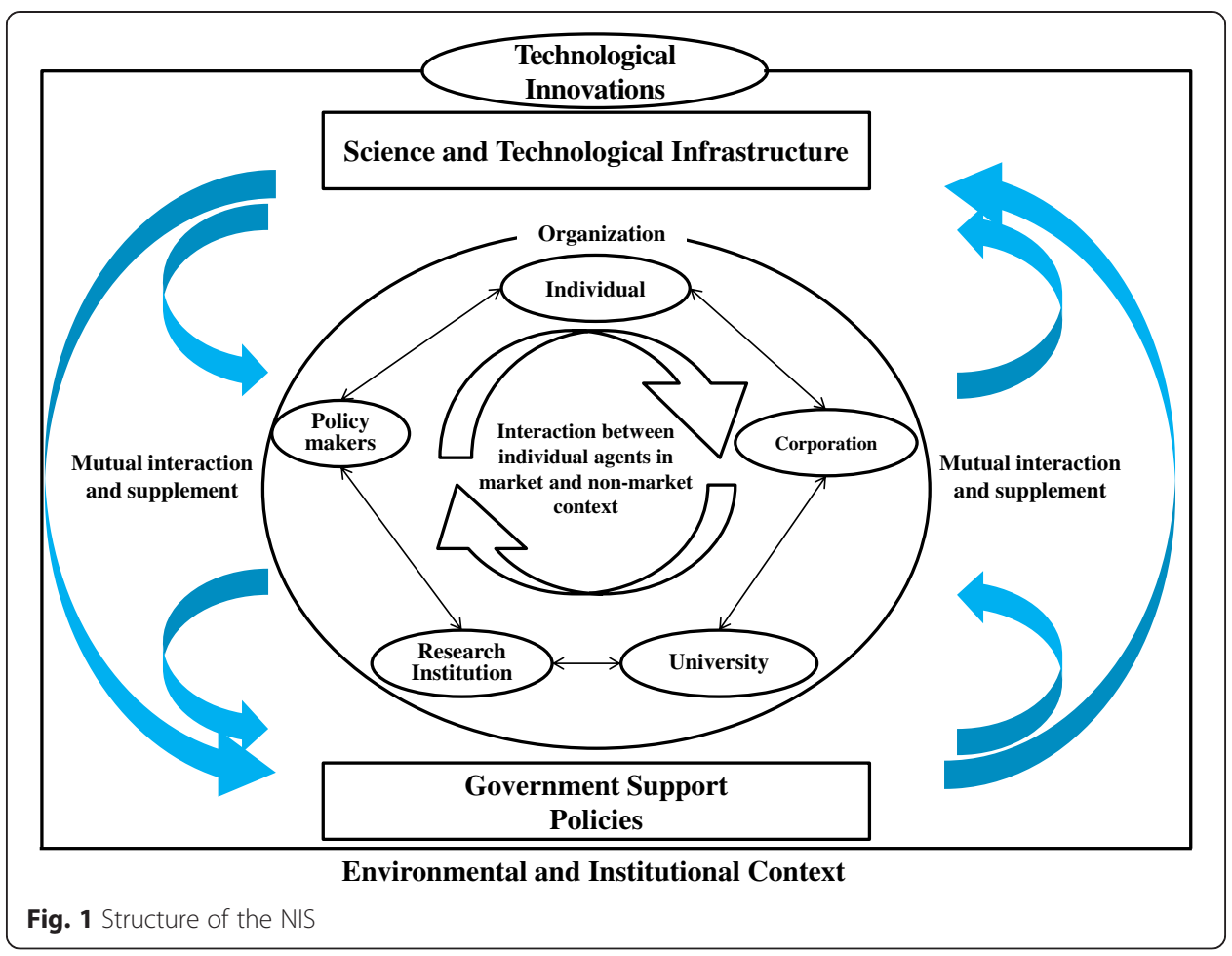

while the relationships among individual constituents form the external circle. Figure 1 shows the process that leads to innovation through the mutual interaction and supplement among innovative agents, the science and technological infrastructure, and government support policies.

\section{Open innovation}

According to Chesbrough (2003), open innovation is defined as the usage of knowledge inflow and outflow from the corporation to accelerate internal innovations and maximize their value by enlarging the market for external utilization (Fig. 2). Thus, it is a paradigm of innovation that uses external ideas in addition to domestic ones to commercialize the firm's technology as well as to open external and domestic ones when establishing a foothold into the market. Considering this, open innovation is an overarching integration of the acquisition, transfer, and commercialization strategies in technologies and products.

With the emphasis on the importance of open innovation, there have been various studies in several dimensions such as firm, industry, and NIS. Firstly, in the dimension of firm, the analysis on the acquisition of technology and commercialization strategies, R\&D efficiency, corporate interactions and strategic profit analysis, as well as technological innovation assessments show the positive effect of open innovation (Amara and Landry 2005; Arora et al. 2001; Chesbrough, 2003; Gassmann and Reepmeyer, 2005; Kline, 2003; Lichtenthaler, 2008). The analysis on the $R \& D$ achievements and effectiveness in accordance with the types of external partners in collaborative activities are being conducted actively 


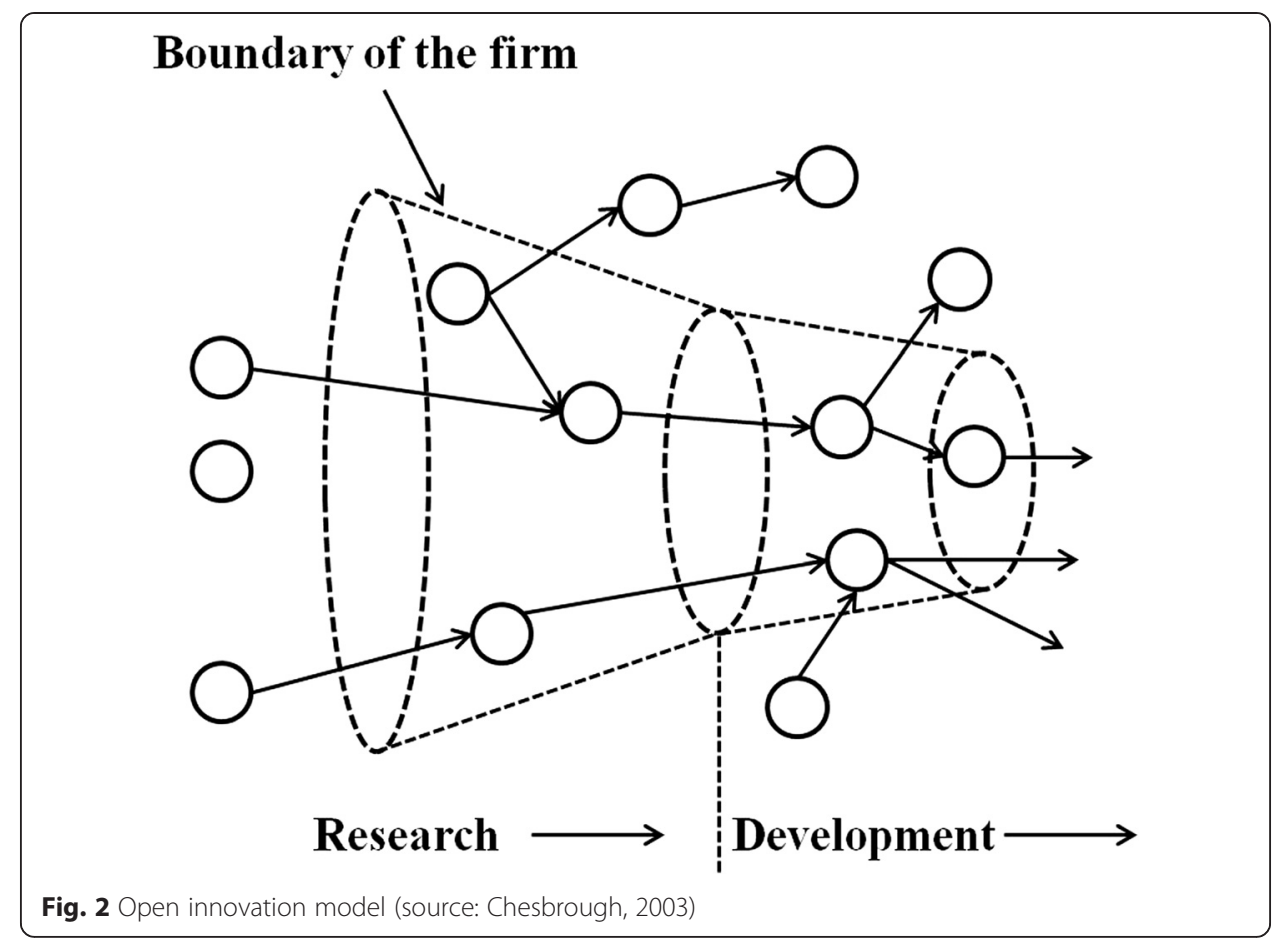

(Belderbos et al. 2004). Han and cho (2015) find the determinants of successful platform business, through the case study of KakaoTalk, a representative fast growing social platform in Korea. Secondly, in the dimension of industry, empirical studies on the effects of collaborative activities and factors that influences the efficiency of R\&D, are being conducted through case studies (Eom and Lee, 2010). Technology planning in accordance with finding collaborative partners in the related industry has been established itself as a research area of open innovation (Jeon et al. 2011). Christensen et al. (2005) insisted that the success of open innovation can differ across technologies and industries. Thirdly, in the dimension of NIS, diverse policies for increasing the open innovation of firms are introduced through networking, collaboration, corporate entrepreneurship, and R\&D (De Jong et al. 2008). Santonen et al. (2007) proposed the innovation triangle framework which consolidates the national open innovation system for supporting the Finnish national system of innovation. Yun et al. (2015) expanded the research on open innovation policy in that it estimated the effects by simulations through an NIS causal loop diagram and system dynamics. This study established that open innovation policies aim at the production as well as the distribution and consumption of knowledge and technologies. Patra and Krishna (2015) explored the structure of linkages of foreign R\&D centers with institutions in India.

Innovation-related journals, such as Research Policy, R\&D Management, Technovation, Technological Forecasting and Social Change, Academy of Management, and Creativity and Innovation Management have engaged on active researches as well. Major forms of advanced researches can be organized as shown in Table 1, while the types of 
Table 1 Several literature Reviews on Open Innovation

\begin{tabular}{|c|c|c|}
\hline Dimension & Subject & Reference \\
\hline \multirow[t]{4}{*}{ Firm } & Importance of technology market & Arora et al. (2001) \\
\hline & Relationship between innovation and R\&D collaboration & $\begin{array}{l}\text { Amara and Landry (2005), Kline } \\
\text { (2003), Lichtenthaler (2008) }\end{array}$ \\
\hline & Open innovation case studies in corporations & $\begin{array}{l}\text { Chesbrough (2003), Gassmann } \\
\text { and Reepmeyer (2005) }\end{array}$ \\
\hline & $\begin{array}{l}\text { Determinants of successful platform business, through the case } \\
\text { study of KakaoTalk }\end{array}$ & Han and cho (2015) \\
\hline \multirow[t]{2}{*}{ Industry } & $\begin{array}{l}\text { R\&D achievements and effectiveness in accordance with the } \\
\text { types of external partners in collaborative activities }\end{array}$ & $\begin{array}{l}\text { Eom and Lee (2010), Belderbos } \\
\text { et al. (2004) }\end{array}$ \\
\hline & Selecting collaborative partner & Jeon et al. (2011) \\
\hline \multirow[t]{4}{*}{ NIS } & Diverse policies for increasing the open innovation & De Jong et al. 2008 \\
\hline & $\begin{array}{l}\text { Innovation triangle framework which consolidates the national } \\
\text { open innovation system }\end{array}$ & Santonen et al. (2007) \\
\hline & $\begin{array}{l}\text { Open innovation policies aim at the production as well as the } \\
\text { distribution and consumption of knowledge and technologies }\end{array}$ & Yun et al. (2015) \\
\hline & $\begin{array}{l}\text { Structure of linkages of foreign R\&D centers with institutions in } \\
\text { India }\end{array}$ & Patra and Krishna (2015) \\
\hline
\end{tabular}

open innovation can be organized as shown in Table 2. However, the majority of the researches are solely focused on case studies centered on corporations, and national level researches remain limited.

\section{Roman period}

Ancient Rome is a civilization that began as a city-state following the settlement of Latins near the Tiber River on $8^{\text {th }}$ century $\mathrm{BC}$, which eventually rose to become a gigantic empire spanning the entire length of the Mediterranean Sea (Kim DS, 2004) (Fig. 3). Over the centuries of its expansion, it progressed from a monarchy to a republic and eventually to an empire. At the time of the $7^{\text {th }}$ century BC, Rome was a prosperous city-space and the center of the surrounding region, ruled by a king (BC 753-509).

Table 2 Types of Open Innovation and Contents

\begin{tabular}{lll}
\hline Method & Concept & Cases \\
\hline In-sourcing & Exploring external technology or know-how & "C\&D" strategy of P\&G \\
R\&D collaboration & R\&D collaboration with external organization (e.g. university) & "Lablet" of Intel \\
Acquisition & Acquisition of a company or a product & M\&As of Cisco \\
User innovation & $\begin{array}{l}\text { Innovation that is performed by the user and not the } \\
\text { supplier }\end{array}$ & Medical Instrument, Toy, \\
Technology licensing & Licensing internal technology outside (sic. Iloutward & Game \\
& licensing of internal technology) & MIPV' of MS \\
Spin-off & Spinning off internal organization & "New venture group" of \\
Joint venturing & Investing venture with venture capital (VC) & Lucent \\
& & Venturing between HP \\
Openning (sic. & Openning (sic. opening) project or source to the public & Linux \\
opening) project & &
\end{tabular}




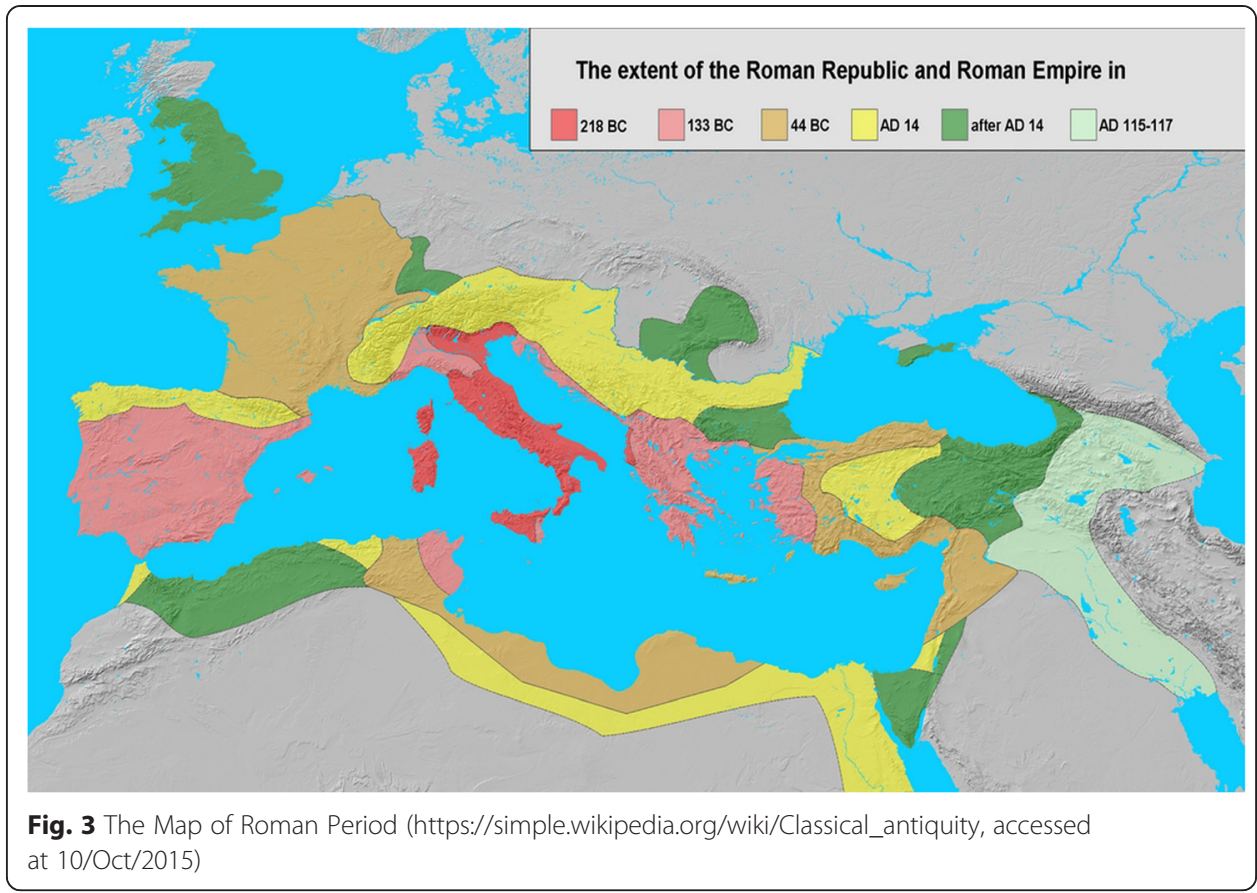

On $5^{\text {th }}$ century $\mathrm{BC}(510 \mathrm{BC})$, the monarchy collapsed, and a republic was established with the collaboration of the nobility and the common people. When Octavianus accepted the title of Augustus from the Senate at the end of the $1^{\text {st }}$ century BC, he became the first emperor of Rome. The early days of the Roman Empire were called "Pax Romana," a time of unprecedented peace and prosperity enforced by the dominance of the empire (Kim DS, 2004). Its openness to the culture and religion of its subjects led to prosperity and integration of its lands, and many different cultures of the Ancient period were assimilated, integrated, and spread among the various constituents of the multicultural and polytheistic empire, including Greece, the Orient, the Semites, and the Western Europe.

The empire, as a result, contributed heavily to the progress of law, politics, arts, literature, architecture, technology, and language of the West. Afterward, the empire eventually split into East and West, the West collapsing on $476 \mathrm{AD}$, the East (Byzantine empire) on $1453 \mathrm{AD}$.

\section{Research framework}

For analyzing the cases of open innovation in Roman period from the viewpoint of the NIS, research flow is shown in Fig. 4. Firstly, from various database about the Roman period, cases of open innovation are collected. Secondly, collected cases are classified according to types of open innovation as shown in Table 2. Thirdly, classified cases are analyzed based on the constituents of NIS. Four major factors of NIS are derived based on the literature review of NIS as shown in Table 3: innovative agent, technological innovation activities, government support policies, environmental and institutional context. Various cases of open innovation of Roman period are analyzed with respect to these four constituents. Finally, implications of Roman period with respect to NIS of open innovation are derived. 


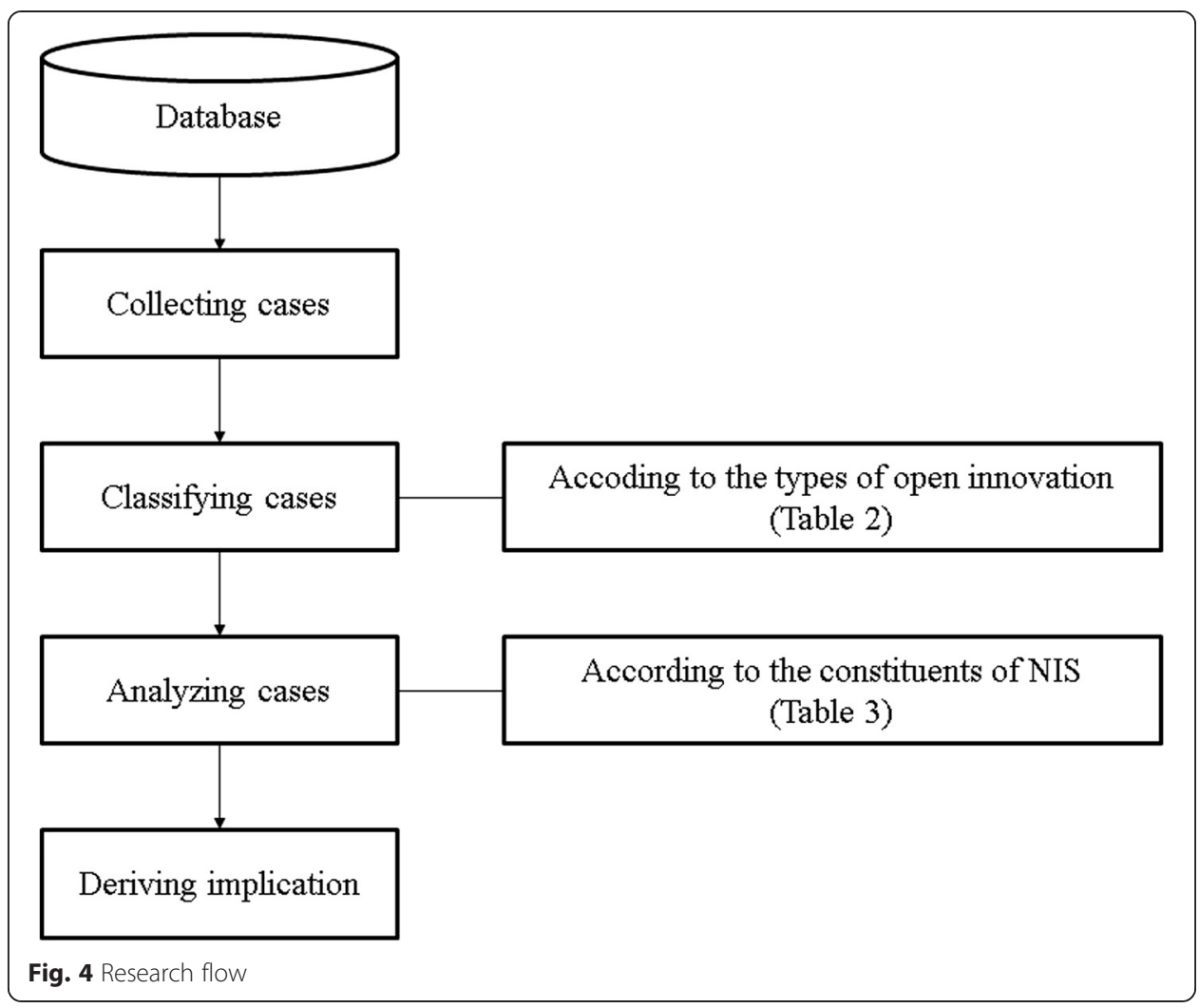

\section{Case study}

The type of acquisition: integration of Non-Romans

A case of open innovation through acquisition may be found in the efforts to integrate non-Romans in the subjects of the empire. Ancient Rome accumulated many subjects through countless number of battles, and unlike other tribes in the Italian Peninsula, it made a conscious effort to integrate its former enemies into the group, even offering citizenships. Also, it recognized the religion and political structure of the subjects. Caesar instituted a policy in which non-Romans with medical skills would be allowed to become a citizen of Rome in exchange for 10 years of medical service in the country, drawing many talented doctors into Rome regardless of race, skin color, place of birth, or social standing. Rome established an environment that allowed not only doctors but also many other talents to be drawn actively from various professions, through which the people of the subject areas rose to nobility and even to the throne. For example, Hispania-born Ulpius Traianus, commander of the $\mathrm{X}$ Legion Fretensis during the Jewish-Roman War and the eventual father of the emperor Trajan, and Julius Agricola, a general from Gaul who was assigned to Britannia, managed to rise to the ranks of the nobility. Also, Trajan (ruled from 98-117) was an emperor from a subject province who led the empire to the height of its territory and widely considered as one of the greatest emperors of the empire. Septimius Severus (193-211), hailing from a subject province in Northern Africa, also rose to the throne. Thus, the ancient Rome formed many policies and institutions to integrate the non-Romans and make use of their talents, and as its territory and the number of non-Romans in its borders grew larger, it 
Table 3 Constituents of NIS

\begin{tabular}{|c|c|c|c|}
\hline Constituents & Definition & Subfactors & Researchers \\
\hline Innovative agent & $\begin{array}{l}\text { Organization who } \\
\text { carry out innovation } \\
\text { in a certain area }\end{array}$ & $\begin{array}{l}\text { Corporate organizations, } \\
\text { noncorporate organizations } \\
\text { (universities, research } \\
\text { institutions, policymakers } \\
\text { etc.), individual }\end{array}$ & $\begin{array}{l}\text { Freeman, 1987; Lundvall, 1992; } \\
\text { Nelson and Rosenberg, 1993; } \\
\text { OECD, 1999; Hong and Lim, 1999; } \\
\text { Lim, 2003; Koo et al., } 2012\end{array}$ \\
\hline $\begin{array}{l}\text { Technological } \\
\text { innovation activities }\end{array}$ & $\begin{array}{l}\text { Process in which an } \\
\text { agent learns and } \\
\text { carries out newly } \\
\text { known product } \\
\text { designs or production } \\
\text { processes, regardless } \\
\text { of being the first to } \\
\text { do so or not }\end{array}$ & $\begin{array}{l}\text { An agent-driven activity } \\
\text { that features agents such } \\
\text { as corporate users, corporate } \\
\text { producers, material and } \\
\text { component corporations, } \\
\text { corporate competitors, and } \\
\text { final consumers. }\end{array}$ & $\begin{array}{l}\text { Freeman, 1987; Lee, 1996; } \\
\text { Lee and Song, 1998; } \\
\text { OECD, } 1999\end{array}$ \\
\hline $\begin{array}{l}\text { Government } \\
\text { support policies }\end{array}$ & $\begin{array}{l}\text { Government policies } \\
\text { designed to support or } \\
\text { foster technological } \\
\text { innovations }\end{array}$ & $\begin{array}{l}\text { Technological demand policy, } \\
\text { supply policy, dissemination } \\
\text { policy, R\&D investment policy, } \\
\text { small and medium enterprise } \\
\text { innovation policy, and local } \\
\text { innovation policy, etc. }\end{array}$ & $\begin{array}{l}\text { Lundvall, 1992; Lee and } \\
\text { Song, 1998; Hong and } \\
\text { Lim, 1999; Seong and } \\
\text { Song, 2007; Song, 2009; } \\
\text { Lee, } 2013\end{array}$ \\
\hline $\begin{array}{l}\text { Environmental and } \\
\text { institutional context }\end{array}$ & $\begin{array}{l}\text { The institutional context } \\
\text { in which a suitable } \\
\text { environment and the } \\
\text { basis of active } \\
\text { technological } \\
\text { innovation can be } \\
\text { established. }\end{array}$ & $\begin{array}{l}\text { Social infrastructure, such as } \\
\text { financial support, patent and } \\
\text { educational policies, culture, } \\
\text { production structure, market } \\
\text { structure, competitive } \\
\text { environment such as } \\
\text { international situation, } \\
\text { science and technology } \\
\text { information network, } \\
\text { information integration, } \\
\text { support organizations, } \\
\text { and R\&D facilities }\end{array}$ & $\begin{array}{l}\text { Freeman, 1987; Lundvall, 1992; } \\
\text { Lee, 1996; Lee and Song, 1998; } \\
\text { Song, 2009; Koo et al. 2012; } \\
\text { Lee, } 2013\end{array}$ \\
\hline
\end{tabular}

adopted the jus gentium, an international law applicable to everyone, both Roman citizens and non-Romans, in the territory.

Open innovation through acquisition, in the form of integration of non-Romans, can be seen as a case study of innovation in national defense and medical system by acquiring talented doctors and soldiers. Table 4 shows the analysis of Rome's acquisition or integration of non-Romans, from the context of the NIS.

Table 4 Case Study Analysis on the Acquisition-type Integration of Non-Romans

\begin{tabular}{|c|c|}
\hline NIS Constituents & Description of case \\
\hline Innovative Agent & Government of Ancient Rome (centered around diplomatic agents) \\
\hline \multirow[t]{2}{*}{ Innovative activity } & $\begin{array}{l}\text { Developing and reforming the manpower inflow system through } \\
\text { acquisition-type innovation in which talented manpower are acquired in } \\
\text { exchange for certain rewards }\end{array}$ \\
\hline & $\begin{array}{l}\text { Because of the inflow of talented soldiers, doctors and educators, innovation of } \\
\text { education, and medical system (especially military hospitals) were made possible. }\end{array}$ \\
\hline $\begin{array}{l}\text { Government Support } \\
\text { Policies }\end{array}$ & $\begin{array}{l}\text { Assigned citizenships to talented doctors in exchange for } 10 \text { years of medical } \\
\text { service, with the goal of acquiring talented doctors regardless of social standing, } \\
\text { race, and birthplace. }\end{array}$ \\
\hline \multirow[t]{2}{*}{$\begin{array}{l}\text { Environmental and } \\
\text { institutional context }\end{array}$} & $\begin{array}{l}\text { Created and applied jus gentium to all citizen within the territory in an equal } \\
\text { manner. }\end{array}$ \\
\hline & $\begin{array}{l}\text { Established an institutional environment in which talented individuals, regardless } \\
\text { of their birthplace, could rise to nobility and office. }\end{array}$ \\
\hline
\end{tabular}


The type of in-sourcing: calendar reform

Ancient Rome initially used a lunar calendar. Julius Caesar, after his conquest of Egypt, ordered the reformation of the calendar into a solar calendar in an example of open innovation through in-sourcing. The pre-Julian lunar calendar was adopted by the $2^{\text {nd }}$ king of Rome, Numa, on $7^{\text {th }}$ century BC and featured 355 days in a year, with leap months added to balance out the days once every few years. The corrections to the calendar was made by the priests of the era in an arbitrary and unscientific fashion. After the conquest of Egypt, however, Rome adopted and reformed the Egyptian solar calendar into what is now known as the "Julian Calendar." Over the course of reform, Egyptian astronomers and Greek mathematicians were called upon to form a research team for the calendar, whose insight into the scientific nature of the calendar allowed them to provide valid amendments to the process. The Earth takes 365 days and $6 \mathrm{~h}$ to make a full orbit around the sun, and the solar calendar as a result takes 365 days as the length of a year. The six-hour difference was corrected by a single day being inserted between the $23^{\text {rd }}$ and the $24^{\text {th }}$ of February every four years, and the resulting "Julian Calendar" was put into effect over the entire territory of the empire, providing a standard for the reckoning of time. This "Julian Calendar" was used until the amendments made by the pope Gregory III on 1582 .

This example of in-sourcing open innovation can be seen as an innovation of time system (or calendar), in which the superiority of the subject land's calendar was recognized, amended through scientific methods and finally put into effect, standardizing all existing calendars into a single system. Table 5 below shows the calendar reform, broken down into subtypes of the NIS.

\section{The type of collaboration: roman alliance}

As an example of open innovation through collaboration, Rome had formed a number of alliances with its surrounding nations. There is a saying that "Rome was built in a day," and this shows that the power of Rome was not formed singularly by the way of military conquests, but rather through an ongoing historical process over the span of centuries through the method of alliances with the surrounding nations. The start of

Table 5 Analysis of Calendar Reform as an In-sourcing-type Open Innovation

\begin{tabular}{ll}
\hline NIS Constituents & Description of case \\
\hline Innovative Agent & $\begin{array}{l}\text { Government of the Ancient Rome (centered around scientific and technological } \\
\text { agents) }\end{array}$ \\
Innovative activity & $\begin{array}{l}\text { Innovation through in-sourcing by the replacement and adoption of a solar cal- } \\
\text { endar in the place of the existing lunar calendar and its unscientific corrective } \\
\text { mechanisms to provide the standardized time and precision }\end{array}$ \\
& $\begin{array}{l}\text { Standardization of time through the usage and distribution of precise and } \\
\text { scientific calendar }\end{array}$ \\
Government Support & $\begin{array}{l}\text { Policies recruiting and supporting the scientists and mathematicians (basic } \\
\text { scientists from Egypt and Greece) for the reformation process. }\end{array}$ \\
Environmental and & By taking in various academic knowledge (engineering, mathematics, science, \\
institutional context & philosophy, etc.) from the conquered lands, academic progress had already been \\
in motion. & $\begin{array}{l}\text { Rome had already received talented individuals in a wide field of knowledge, } \\
\text { including the basic sciences, and had formed a talented pool of researchers } \\
\text { beforehand. }\end{array}$ \\
\hline
\end{tabular}


the alliance-building can be traced to the end of the $6^{\text {th }}$ century BC, when the Roman Republic had just been formed. The first alliance that the fledgling republic had sought was the Latin League, made up of regional nations in the Latium area. Latin League was an alliance that formed and headed the Kingdom of Rome as a means to provide a common offering to the god, Jupiter, on the Alban Mount. However, the league was reformed by the Treaty of Cassius on $493 \mathrm{BC}$, which was outwardly a treaty of equality and reciprocity but had, in reality, elevated Rome onto the head of the league. The Latin League formed the springboard from which Rome initiated the conquests of Etruscans, Sabines, Aequians, and Volscians. The members of the league, however, voiced their opposition to the League, which had increasingly become a tool for the Romans, and began to deviate and oppose the league and the Rome at times of their weakness. To mitigate these opposition, Rome began to reform the alliance, binding the member states with bilateral treaties and prohibiting individual treaties among the member states. Those nations, which accepted these reforms, received Roman citizenship as a member of the Roman nation. Also, the opposition were destroyed and their politicians banished from the territory. Over the course of these alliances, Rome allowed self-governance for the member states, and coupled with a series of successful wars, it established itself as the ruler of the Italian Peninsula. Figure 5 shows the relationship structure in the Latin League and the Roman Alliance after the reformation.

With collaboration-type innovation and internal reforms, Rome established an effective system of collaboration between nations with Rome at its helm. Also, through these alliances Rome was able to acquire talented manpower into Rome, and acquired the drive to sustain continuous territorial expansions. Table 6 shows the analysis of the collaboration-type innovation in the NIS standpoint.

\section{The type of user innovation: adopting military technology from surrounding nations}

As a form of user innovation, the Rome adopted military technology from the surrounding nations. The military of Ancient Rome was based on the weapons and the tactics of the Greeks. For example, the basic combat formation of "Phalanx" with long spears and circular shields was derived from the Greeks. However, with territorial

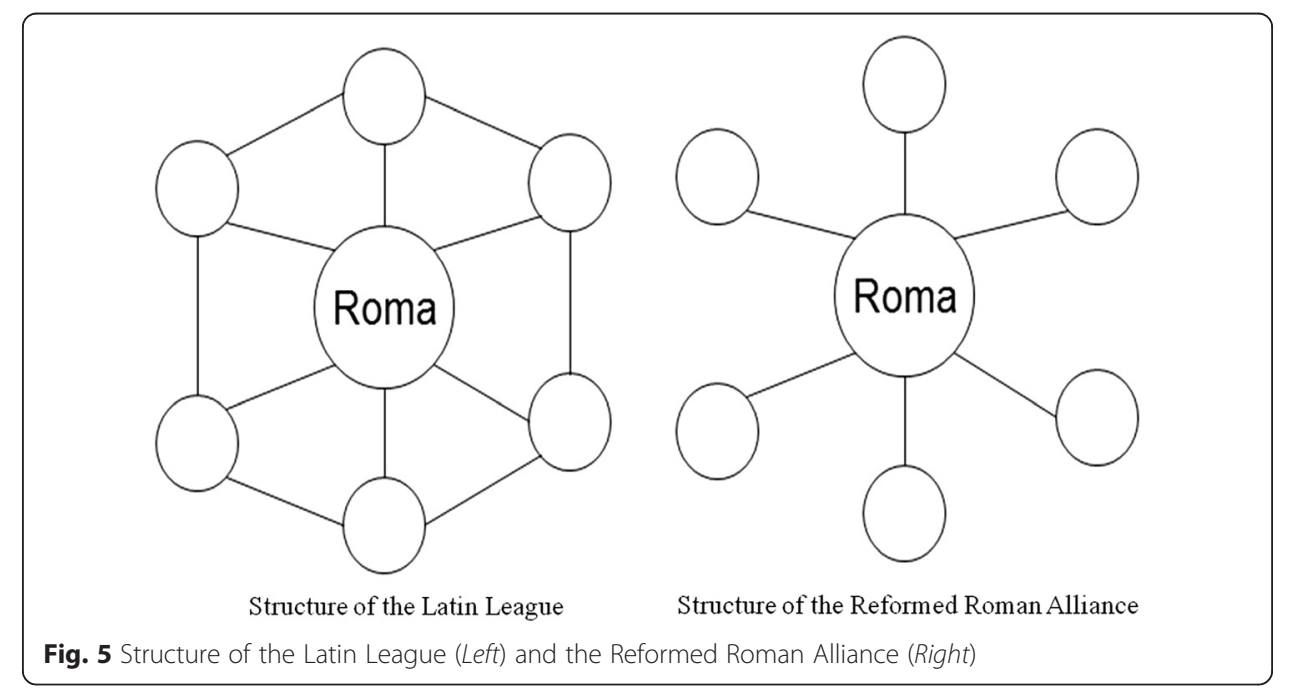


Table 6 Collaboration-type Roman Alliance Analysis

\begin{tabular}{ll}
\hline NIS Constituents & Description of case \\
\hline Innovative Agent & Government of Ancient Rome (centered around diplomatic agents) \\
Innovative Activity & Collaboration through the formation and the reformation of collaborative \\
& systems (Latin League) among the member states to manage the territorial wars \\
& and subjects effectively. \\
& Restructuring of relationship between Rome and member states, and among the \\
& member states themselves to mitigate the opposition to the previous \\
& collaborative activity and maintain loyalty (Roman Alliance) \\
& Through mutual equality treaties among the member states, centered around \\
Government Support & Rome, the member states were assigned the same profits (spoils, military \\
Policies & provisions, and allowances from war), rights (citizenship with suffrage, marriage \\
& Allowed bilateral treaties between Rome and member states only, and not \\
& among the member states \\
& The planned territorial expansions to both southern and northern areas in the \\
& Italian Peninsula and support from the surrounding nations played heavy \\
importance in combat personnel and logistics support
\end{tabular}

expansions and the resulting variations in terrain, the military techniques of the Greeks proved to be insufficient. The Roman capacity for openness showed itself in military situations as well. In mountainous regions, long spears were discarded after their limitations were recognized, and short swords were adopted in their stead. The short swords in question were the modified versions of the Iberian "Gladius." Also, recognizing the dangers of javelins used by the Samnites, the Romans adopted the javelin "Pilum," which eventually was developed into the "Plumbata," which was light enough for a soldier to carry multiple shafts. As the equipment of the army underwent changes, the combat and defense formations and techniques changed subsequently as well. Figure 5 shows the contrast on the pre-user innovation equipment and combat formations with the ones after the innovation.

These examples of user innovations show a specialized variety of innovation in the military systems following the territorial expansion and the increased varieties in terrain. Overall, it can be seen as an example of a general innovation in national defense, through the acquisition of new weapon systems and defense planning. Table 7 presents the analysis of the user innovation in the NIS standpoint.

\section{The type of spin-off: building roads and cities}

Through a series of innovations and technological influx from the Greeks and the surrounding nations, the Roman architecture technology, along with its military, became the centerpiece of the outstanding technology that the Romans possessed. The Roman architecture, in particular, adopted precise and rigorous plans and proportions from the Greeks and featured significant architectural elements like composite and Tuscan columns, a new way of arranging shafts and capitals, and dome technology from Etruscan arches. Figure 6 shows the examples of Etruscan structures. These technology were applied not only in the Rome proper but also in the conquered lands. Recognizing that the roads signify the commitment to territorial alliances, Rome built many roads that were all linked to Rome, through which 
Table 7 Analysis of User Innovation Type and adoption of Military Technology from Surrounding Nations

\begin{tabular}{|c|c|}
\hline NIS Constituents & Description of case \\
\hline Innovative Agent & Government of Ancient Rome (centered around military agents) \\
\hline \multirow[t]{2}{*}{ Innovative Activity } & $\begin{array}{l}\text { User innovation from the recognition of limitations in existing weapon systems } \\
\text { and adopting, modifying, and making use of foreign weapon systems }\end{array}$ \\
\hline & $\begin{array}{l}\text { Caused innovation to spread to the military systems in general, affecting various } \\
\text { areas such as military strategy }\end{array}$ \\
\hline $\begin{array}{l}\text { Government Support } \\
\text { Policies }\end{array}$ & $\begin{array}{l}\text { Assimilating skilled military personnel from conquered lands or issuing tailored } \\
\text { strategies to legions }\end{array}$ \\
\hline \multirow[t]{2}{*}{$\begin{array}{l}\text { Environmental and } \\
\text { Institutional Context }\end{array}$} & $\begin{array}{l}\text { The increased pace in territorial expansion and war made the usage of the } \\
\text { existing Greek systems risky. }\end{array}$ \\
\hline & $\begin{array}{l}\text { All military personnel (leadership and soldiers) were aware of the threats posed } \\
\text { by the weapon systems of the natives, which were tailored to the battlefield } \\
\text { conditions. }\end{array}$ \\
\hline
\end{tabular}

political, military, administrative, cultural, and technological ideas were disseminated to the conquered lands. The roads in Rome, made of concrete, were notable for their sturdy construction and were used even after a thousand years from the fall of the empire. The efficient road network stretched to 50,000 miles in length, constantly playing its part in enlarging the hegemony in Rome and its sphere of influence. For example, the Via Appia (312 BC), linking Rome and Capua, is still in use today (Jung JY, 2007). Roman construction in conquered lands allowed their engineering skills (roads, buildings, sewage, etc.) to spread to the conquered lands, and the resultant urban renewal projects allowed the conquered lands to fulfil its purpose as a model of Roman self-governance, rear area defensive base, and economic center of the region (Fig. 7).

These examples of spin-off technologies can be seen as an example of innovation which allowed the formation of Roman network, through which technological and cultural disseminations and administrative support could be efficiently conducted. Through these innovations, an infrastructure was built that allowed for the flow of various knowledge, economic resources and technology. Table 8 shows the examples of Roman spin-off type road and city-building projects.

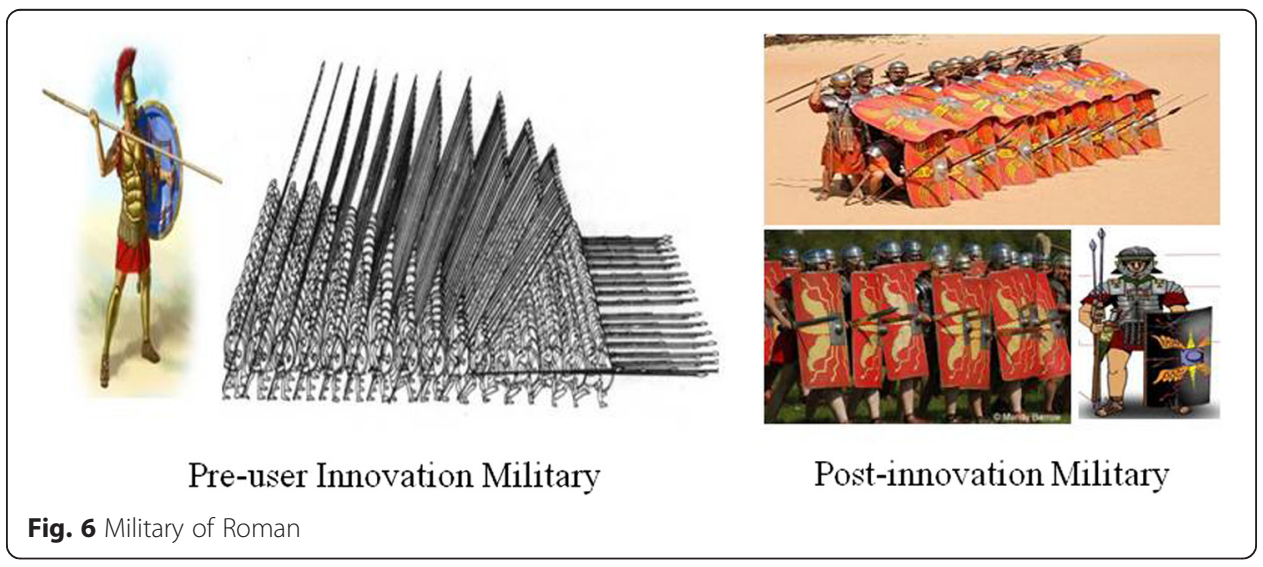




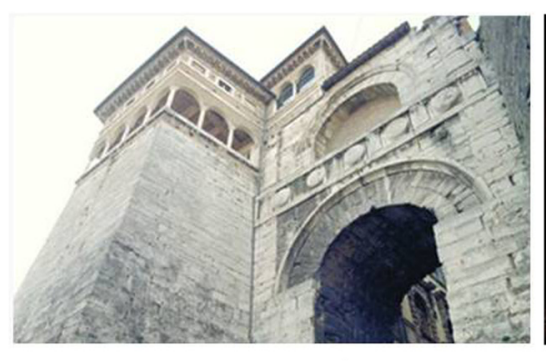

Etruscan Arch

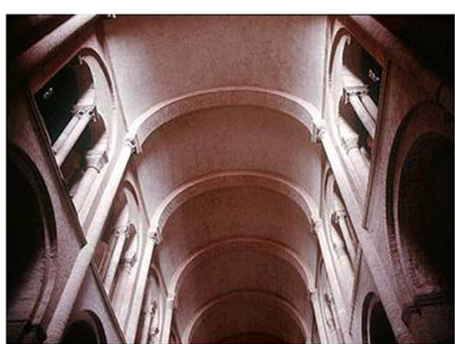

Circular Dome

Fig. 7 Building Structures of Roma

\section{Discussion and conclusion}

\section{Theoretical and managerial implications}

This research attempted to analyze the case studies of open innovation in the Roman period from the NIS standpoint, with the aim of understanding the relationship between open innovation and the NIS. Through this, the study focused on the national examples of open innovation, instead of the corporate-centered examples that had featured heavily in literature. In particular, among various different types of open innovation, the Roman equivalents of acquisition, in-sourcing, collaboration, user innovation, and spin-off types were analyzed over the course of this study. By reviewing the literature on the NIS, the constituents and the organization of the NIS has also been reworked for application to the Roman Period. The constituents of the NIS were organized into four major subtypes: the innovative agent, innovative activity, government support policies, as well as environmental and institutional factors, and the summary of the case studies are provided on the Table 9. This result is expected to help present policy officers make the 'Open' NIS. For example, with respect to innovative agent, various organizations such as diplomacy, science and technology, military can conduct open NIS. In the case of acquisition in NIS, encouraging innovations in various fields are needed such as education and medicine through the influx of talented

Table 8 Spin-off-type Road and Urban Construction Analysis

\begin{tabular}{ll}
\hline NIS Constituents & Description of case \\
\hline Innovative Agent & Government of the Ancient Rome (centered around territory management) \\
Innovative Activity & $\begin{array}{l}\text { By applying the Roman style of road and urban construction in the conquered } \\
\text { lands, architecture technology could be spun off to the conquered lands } \\
\\
\text { Formed networks in the conquered lands that allowed them to receive various } \\
\text { military, political, administrative, cultural, technological knowledge and } \\
\text { regulations and at the same time serve as a strategic base for administration }\end{array}$ \\
Government Support & $\begin{array}{l}\text { Adopting and disseminating superior technology of the subjects } \\
\text { Policies }\end{array}$ \\
& $\begin{array}{l}\text { Providing support to outsourcing policies targeting locals to utilize the } \\
\text { Environmental and }\end{array}$ \\
Institutional Context & $\begin{array}{l}\text { Relative superiority of architecture and cityscape engineering technology in } \\
\text { surrounding nations (Etruscan civil engineering and construction, Greek } \\
\text { planning, etc.) } \\
\text { Rome required various architectural technology (construction as well as civil and } \\
\text { cityscape engineering), because it was still in its developing stages at that point }\end{array}$
\end{tabular}


Table 9 Analysis of Case Study of Open Innovation from the Standpoint of the NIS

\begin{tabular}{|c|c|c|c|c|c|}
\hline \multirow{2}{*}{$\begin{array}{l}\text { NIS } \\
\text { constituents }\end{array}$} & \multicolumn{5}{|c|}{ Open innovation type } \\
\hline & Acquisition type & In-sourcing type & $\begin{array}{l}\text { Collaboration } \\
\text { type }\end{array}$ & $\begin{array}{l}\text { User innovation } \\
\text { type }\end{array}$ & Spin-off type \\
\hline $\begin{array}{l}\text { Innovative } \\
\text { agent }\end{array}$ & Diplomacy & $\begin{array}{l}\text { Science and } \\
\text { technology }\end{array}$ & Diplomacy & Military & $\begin{array}{l}\text { Territorial } \\
\text { management }\end{array}$ \\
\hline $\begin{array}{l}\text { Innovative } \\
\text { activity }\end{array}$ & $\begin{array}{l}\text { Encouraging } \\
\text { innovations in } \\
\text { various fields } \\
\text { such as } \\
\text { education and } \\
\text { medicine } \\
\text { through the } \\
\text { influx of talented } \\
\text { personnel and } \\
\text { non-Romans in } \\
\text { exchange for } \\
\text { citizenship }\end{array}$ & $\begin{array}{l}\text { Adopting and } \\
\text { reforming the } \\
\text { scientific and } \\
\text { precise solar } \\
\text { calendar as well } \\
\text { as the basic } \\
\text { scientists from } \\
\text { the conquered } \\
\text { lands, thereby } \\
\text { standardizing the } \\
\text { time }\end{array}$ & $\begin{array}{l}\text { Establishing } \\
\text { collaborative } \\
\text { systems and } \\
\text { reforming such } \\
\text { networks to } \\
\text { provide combat } \\
\text { support and } \\
\text { efficient } \\
\text { management of } \\
\text { conquered } \\
\text { territories }\end{array}$ & $\begin{array}{l}\text { Innovations in } \\
\text { military system } \\
\text { through } \\
\text { territorial } \\
\text { expansions and } \\
\text { wars, such as } \\
\text { adopting } \\
\text { suitable weapon } \\
\text { system and } \\
\text { combat } \\
\text { formations or } \\
\text { reforms in } \\
\text { strategy and } \\
\text { tactics }\end{array}$ & $\begin{array}{l}\text { Adopting foreign } \\
\text { technology to } \\
\text { urban } \\
\text { construction } \\
\text { projects in } \\
\text { conquered lands, } \\
\text { and fostering } \\
\text { architectural } \\
\text { reforms } \\
\text { throughout the } \\
\text { territories by } \\
\text { disseminating } \\
\text { relevant } \\
\text { technology to } \\
\text { subject lands. }\end{array}$ \\
\hline $\begin{array}{l}\text { Government } \\
\text { Support } \\
\text { Policies }\end{array}$ & $\begin{array}{l}\text { Enacted a policy } \\
\text { to assign } \\
\text { obligations for } \\
\text { medical service } \\
\text { in certain areas } \\
\text { with citizenship }\end{array}$ & $\begin{array}{l}\text { Provided support } \\
\text { to } \\
\text { mathematicians } \\
\text { and earth } \\
\text { science } \\
\text { personnel } \\
\text { regardless of } \\
\text { their home } \\
\text { nation or } \\
\text { birthplace }\end{array}$ & $\begin{array}{l}\text { Assigned equal } \\
\text { profits, rights, } \\
\text { and duties to the } \\
\text { subjects and } \\
\text { prohibited } \\
\text { treaties between } \\
\text { subject nations }\end{array}$ & $\begin{array}{l}\text { Assimilated and } \\
\text { adopted superior } \\
\text { military elements } \\
\text { into the ranks } \\
\text { and assigned } \\
\text { suitable } \\
\text { strategies } \\
\text { tailored to } \\
\text { individual } \\
\text { legions. }\end{array}$ & $\begin{array}{l}\text { Assimilated } \\
\text { superior } \\
\text { technology or } \\
\text { technicians from } \\
\text { subject lands and } \\
\text { assigned } \\
\text { outsourcing } \\
\text { projects to these } \\
\text { technicians when } \\
\text { the construction } \\
\text { requires their } \\
\text { specialty }\end{array}$ \\
\hline $\begin{array}{l}\text { Environmental } \\
\text { and } \\
\text { institutional } \\
\text { context }\end{array}$ & $\begin{array}{l}\text { Established a } \\
\text { social } \\
\text { environment in } \\
\text { which all capable } \\
\text { men can rise } \\
\text { into the office } \\
\text { and enacted jus } \\
\text { gentium, a law } \\
\text { that is applied } \\
\text { equally to all } \\
\text { citizens } \\
\text { regardless of } \\
\text { their background }\end{array}$ & $\begin{array}{l}\text { Influx and } \\
\text { adoption of } \\
\text { various academia } \\
\text { due to territorial } \\
\text { expansions and } \\
\text { conquests, } \\
\text { research teams } \\
\text { formed in various } \\
\text { areas }\end{array}$ & $\begin{array}{l}\text { The Surrounding } \\
\text { nations were, in } \\
\text { overall, positive } \\
\text { about having an } \\
\text { alliance with } \\
\text { Rome, and many } \\
\text { approved the } \\
\text { openness of } \\
\text { Rome. }\end{array}$ & $\begin{array}{l}\text { The increase in } \\
\text { the pace of } \\
\text { combat in both } \\
\text { southern and } \\
\text { northern regions, } \\
\text { and maintaining } \\
\text { existing systems } \\
\text { were risky }\end{array}$ & $\begin{array}{l}\text { Surrounding } \\
\text { nations had } \\
\text { superior } \\
\text { technology in } \\
\text { architecture and } \\
\text { construction } \\
\text { technology, } \\
\text { making adoption } \\
\text { of such } \\
\text { technology } \\
\text { feasible }\end{array}$ \\
\hline
\end{tabular}

personnel and non-countries in exchange for citizenship. Table 10 shows the summary about types and cases of open innovation in corporate and national perspectives.

While the majority of the literature focused on a corporate-level analysis of open innovation, this study attempted to provide a national-level analysis through the standpoint of the NIS, with the following significant points. First, this study shows that any analysis of open innovation must be made according to the size of the innovative agent. There were many cases of open innovation with various sizes in the agents, and these examples affect their development. The analysis may be made not only in the standpoint of national entities but also in local and global innovation systems, and through such analysis, significant lessons may be learned from the development process of the agents involved. Second, by referring to the cases of open innovation in the NIS of the historical powers, this study shows the importance of a suitable innovation system to the individual nations for a modern nation to join the ranks of the powerful. In the 
Table 10 Types and Cases of Open Innovation in Corporate and National Perspectives

\begin{tabular}{llll}
\hline Method & Company level & National level \\
\cline { 2 - 3 } & Concept & Cases & Cases \\
\hline In-sourcing & $\begin{array}{l}\text { Exploring external technology or know- } \\
\text { how }\end{array}$ & $\begin{array}{l}\text { "C\&" strategy of } \\
\text { P\&G }\end{array}$ & Caesar's Calendar Reform \\
R\&D & R\&D collaboration with external & "Lablet" of Intel & Roman Alliance \\
collaboration & organization (e.g., university) & & \\
Acquisition & Acquisition of a company or product & M\&As of Cisco & Embracing non-Romans \\
User & Innovation that is performed based on & Medical & Adopting military technology \\
innovation & user and not the supplier & Instrument, Toy, & from surrounding nations \\
Spin-off & Spinning off internal organization & "Name & \\
& & "Now venture & Roman road and urban \\
\end{tabular}

NIS, the factors that affect the innovation, such as culture, institution, as well as scientific and technological infrastructure are becoming ever more diverse and developed. To keep up with these changes, a suitable NIS must be sought to pinpoint the direction of the innovation.

\section{Limitations and future research}

Although there are some meaningful implications in this study, our research has some limitations. This study cannot reliably provide a framework of analysis to other nations because of the continuous evolution of the process and the differences in the NIS of individual nations. Also, the framework for the analysis of the NIS, which is used in this study, does not represent precisely the changes in civilization at the time of Ancient Rome. Thus, for future studies, the changes in civilization and the characteristics of the NIS must be derived and applied in addition to those of the Ancient Rome. Also, other case studies on various types of open innovation in a national level must be discovered and analyzed, and the lessons for the nation in question must be derived as well.

Competing interests

The authors declare that they have no competing interest.

\section{Authors'contributions}

$\mathrm{JH}$ carried out the open innovation studies and drafted the manuscript. SKK carried out the national innovation system studies. JHK carried out the Roman period studies. All authors read and approved the final manuscript.

\section{Acknowledgement}

This research was supported by Basic Science Research Program through the National Research Foundation of Korea (NRF) funded by the Ministry of Education (NRF-2015R1D1A3A01020667).

\footnotetext{
Author details

${ }^{1}$ Department of Industrial and Systems Engineering/ERI, Gyeongsang National University, Gyeongsangnam-do, Korea.

${ }^{2}$ Department of Electronics Engineering/ERl, Gyeongsang National University, Gyeongsangnam-do, Korea.
}

Received: 31 August 2015 Accepted: 8 December 2015

Published online: 22 December 2015

\section{References}

Amara N, Landry R. Sources of Information as Determinants of novelty of Innovation in Manufacturing Firms: Evidence from the 1999 Statistics Canada innovation Survey. Technovation. 2005;25:245-59.

Arora A, Fosfuri A, Gambardella A. Markets for Technology: The Economics of Innovation and Corporate Strategy. Cambridge: MIT Press; 2001.

Belderbos R, Carree M, Lokshin B. Cooperative R\&D and firm performance. Res Policy. 2004;33(10):1477-92.

Chesbrough H. Open innovation: The New Imperative for Creating and Profiting From Technology. Boston: MA: MBS; 2003.

Christensen JF, Olesen MH, Kjaer JS. The industrial dynamics of open innovation-Evidence from the transformation of consumer electronics. Res Policy. 2005;34:1533-49. 
De Jong J, Kalvet T, Vanhaverbeke W. Exploring a theoretical framework to structure the public policy implications of open innovation. Technol Anal Strateg. 2010;22(8):877-96.

De Jong J, Vanhaverbeke W, Kalvet T, Chesbrough H. Policies for Open Innovation: Theory, Framework and Cases, Research project funded by VISION Era-Net, Helsinki, 2008.

Eom B, Lee K. Determinants of industry-academy linkages and their impact on firm performance: the case of Korea as a latecomer in knowledge industrialization. Res Policy. 2010;39:625-39.

Freeman C. Technology Policy and Economic Performance: Lessons from Japan, Pinter Publishers; 1987.

Gassmann O, Reepmeyer G. Organizing pharmaceutical innovation: From science-based knowledge creators to drug-oriented knowledge brokers". Creat Innov Manag. 2005;14:233-45.

Han JH, Cho OJ. Platform business Eco-model evolution: case study on KakaoTalk in Korea. J Open Innov: Technol Mark Complexity. 2015;1:6.

Hong SG, Lim YC. A conceptual framework about improvement direction of national innovation system in 21 century STEPI. Sci Policy. 1999;10(1):88-98.

Hong YS. Innovation of national innovation system, STEPI. Science Policy, 2007;(166):1-5. https://simple.wikipedia.org/ wiki/Classical_antiquity (accessed at 10/Oct/2015)

Jang WJ, Lee CJ. A Study on the Application of Open Innovation Concept for the Defense Science and Technology Innovation. J Korea Technol Innov Soc. 2009;12(2):312-34.

Jeon J, Lee H, Park Y. Implementing technology roadmapping with supplier selection for semiconductor manufacturing companies. Technol Anal Strateg. 2011;23(8):899-918.

Johnson AS, Jacobsson. The Emergence of a Growth Industry: A Comparative Analysis of the German, Dutch and Swedish Wind Turbine Industries. In: Metcalfe JS, Cantner U, editors. Transformation and Development: Schumpeterian Perspectives. Heidelberg: Physical Springer; 2003.

Jung JY. The history of architecture technology. Daejeon: Glnuri; 2007

Kim DS. Greece and Roma, Sallimbooks; 2004

Kline D. Sharing the Corporate Crown Jewels. MIT Sloan Manag Rev. 2003;44:89-93.

Koo YW, Cho SB, Min WK. The Evolution of the Systems of Innovation Approach: A Review of the Main Issues. J Korea Technol Innov Soc. 2012;15(2):225-41.

Lee GL, Song WJ. The Structure and Characteristics of the Korean National Innovation System, STEPI. Res Study. 1998:1:0.

Lee GL. Components of National Innovation System - Their Roles and Interactions. KISTI Sci Policy Trend. 1996;6(7):53-67.

Lee $\mathrm{MH}$. The converting direction and project of national innovation system for creative economy. STEPI, Issues \& Policy. 2013;72:0.

Lee SM. Science \& Technology Policy Types in National Innovation System: a Comparative Case Study on the United States and Germany. Korean Policy Stud Rev. 2009;18(3):159-85.

Lee WY, Moon MS, Sung TJ, Shin SW. S\&T Policy Issues of Gyeonggi-do and Policy Recommendations, GRI; 2007

Lee $\mathrm{MH}$, Ahn DH, Jeong ME, Lee HJ, Koh YJ, Byun YJ. The efficiency plan of role and operating system governmentcontributed research institute for improvign the research result, STEPI. Policy Res. 2012;2012(2):1-221.

Lichtenthaler U. Integrated roadmaps for open innovation. Res Technol Manage. 2008:51(3):45-9.

Lim CS. The feature and implication of national innovation system in Europe small but strong country, STEPI. Policy Res. 2003;13:1-170.

Lim CS. Small Economy Innovation Systems: comparing globalization, change and policy in Asia and Europe, STEPI. Policy Res. 2006;19:1-204.

Lundvall B. Introduction. In: Lundvall B, editor. National Systems of Innovation. London and New York: Pinter Publisher; 1992.

Moon HS. The research about invigoration of R\&D partnership under the national innovation system, STEPI. Policy data, 2006;10:1-51.

Nelson R, Rosenberg N. Technical innovation and national systems, Nelson R(eds). National innovation systems: a comparative analysis. New York: Oxford University; 1993.

OECD. NISs. Paris: Organization for economic cooperation and development; 1997.

OECD. Technology and economy: The key relationship, Translated by Lee et al., Kyungmoon; 1992

OECD. Managing National Innovation Systems. Paris: OECD; 1999.

Patel P, Pavitt K. NIS: Why they are important and how they might be measured and compared. Econ Innov New Technol. 1994;3:77-95.

Patra SK, Krishna W. Globalization of R\&D and open innovation: linkages of foreign R\&D centers in India. J Open Innov: Technol Mark Complexity. 2015;1:7

Santonen T, Kaivo-oja J, Suomala J. Introduction to national open innovation system (NOIS) paradigm, A Preliminary Concept for Interchange, FFRC eBooks, 2007:8, http://www.utu.fi/fi/yksikot/ffrc/julkaisut/e-tutu/Documents/eTutu 2007-8.pdf, accessed 5 December 2015.

Schiele H. Early supplier integration: the dual role of purchasing in new product development. R\&D Manag. 2010;40(2):138-53.

Seo JH. Science and Technology Promotion For developing Knowledge-Based Economy, in vision and strategy of national innovation, SERl; 1998

Seong JE, Song WJ. The theory and application of holistic innovation policy: Cases of Finland and Korea. Journal of Korea technology innovation society. 2007;10(3):2007.

Song WJ. Policy theory of National Innovation System, STEPI. Working Paper. 2009;1:0-0.

Vanhaverbeke W, Cloodt M. Open Innovation in Value Networks. In: Chesbrough H, Vanhaverbeke W, West J, editors. Open Innovation: Researching a New Paradigm. Oxford Press: Oxford; 2006.

Wang Y, Vanhaverbeke W, Roijakkers N. Exploring the impact of open innovation on national systems of innovation: A theoretical analysis. Technol Forecast Soc. 2012;79(3):419-28.

West J, Vanhaverbeke W, Chesbrough H. Open Innovation: A Research Agenda. In: Chesbrough H, Vanhaverbeke W, West J, editors. Open Innovation: Researching a New Paradigm. Oxford Press: Oxford; 2006.

Yun JJ, Won D, Hwang B, Kang J, Kim D. Analysing and simulating the effects of open innovation policies: Application of the results to Cambodia. Sci Publ Pol. 2015;42(1):1-18. 